\title{
The birds and the bees
}

SIR - Many Loranthaceae mistletoes, including Peraxilla in New Zealand, have 'explosive' flowers which cannot open themselves; birds pop the buds open and pollinate them ${ }^{1}$. However, a reduction in bird density has decreased visitation rates in some areas and depressed seed production in these plants ${ }^{2}$. Here we report that tiny native solitary bees (Hylaeus sp.) can successfully prise open Peraxilla tetrapetala buds, which is to our knowledge the first documented case of an invertebrate opening an explosive, bird-pollinated flower. The bee is inefficient at pollen transfer, but still doubles the number of seeds ripened per flower. This example is an extreme case of ecological replacement of vertebrates by an invertebrate in a depauperate island fauna.

Peraxilla flowers are relatively large (27-42 mm); ripe buds open only with considerable force, from a beak or a human hand, for example. The main pollinators are honeyeaters ${ }^{1}$ : tui (Prosthemadera novaeseelandiae, mass $120 \mathrm{~g}$ ) and bellbirds (Anthornis melanura, $30 \mathrm{~g}$ ). Explosive flowers worldwide are usually bird-opened, exclusively so in the Loranthaceae ${ }^{3}$. Insecttripped explosive flowers occur in several families, such as Cytisus scoparius (Fabaceae) $)^{4,5}$, but there are no previous reports of any explosive flower that can be

Fruit-set in Peraxilla under various pollination treatments

Pollination treatment

P. tetrapetala

P. colensoi

Unopened

Bee-opened, birds excluded

Hand-opened, birds excluded

$16.3^{*}$

$30.7^{+}$

$48.2^{\text {市 }}$

$28.3^{*+}$

Control, naturally opened

$66.3^{\ddagger}$

Hand-opened, hand-pollinated

Residual variance (with residual d.f.)

Model: Null

Plant

$176.8(34)$

$88.55(27)$

Plant, treatment

$31.44(23)$

Probability (treatment)

$<0.001$

Fruit-set is defined as the percentage of flowers ripening their solitary ovule. We carried out treatments in summer 1995-96 in the field at Craigieburn, Canterbury $\left(43^{\circ} 9.2^{\prime} \mathrm{S}, 171^{\circ} 42.7^{\prime}\right.$ E) for P. tetrapetala and at Wakefield, Nelson $\left(41^{\circ} 25.5^{\prime} \mathrm{S}\right.$, $173^{\circ} 2.5^{\prime} \mathrm{E}$ ) for $P$. colensoi. Pollination treatments were as follows. Unopened: buds within wire-mesh bird-exclosures which remained unopened until petal abscission, see ref. 1; beeopened, birds excluded: opened by bees within the exclosures; hand-opened, birds excluded: buds were opened with human pollen transfer minimized and left accessible to insects; controls: flowers accessible to birds and insects and naturally opened; hand-opened hand-pollinated: abundant outcross pollen but birds excluded. All treatments were replicated within plants as blocks ( $n=6$ for $P$. colensoi and 7 for $P$. tetrapetala) and analysed for each species using a generalized linear model with binomial error and logit link function. In each species treatment was highly significant. Comparisons among means were done using t-tests on generalized linear model-generated means (and s.e.m.) for pairs of treatment groups; means within a species indicated by the same symbols $(* \dagger \neq)$ do not differ significantly $(P>0.05)$.

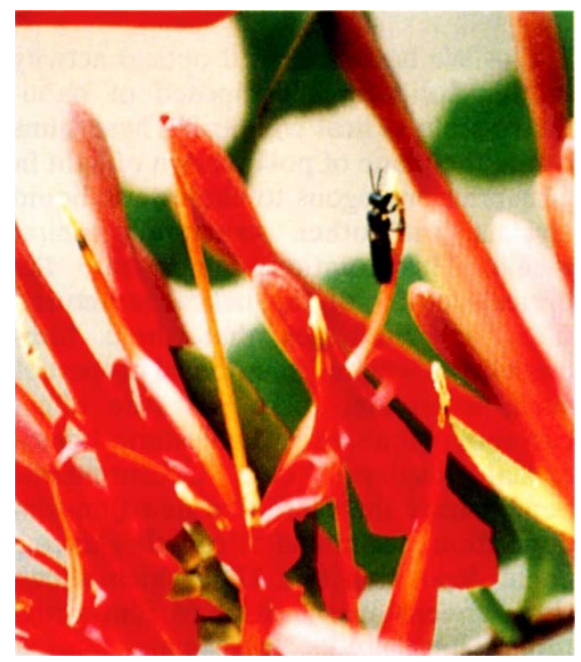

A native bee (Hylaeus sp.) harvesting pollen from the explosive-flowered mistletoe $P$. colensoi at Wakefield, New Zealand. Although the flowers are normally bird-opened, Hylaeus can open flowers of $P$. tetrapetala, but not $P$. colensoi. The bee is so small that it may not regularly contact the stigma in either species, but $P$. tetrapetala flowers opened by these bees do ripen more seeds.

populations may promote speciation via pollination syndrome shifts, like the one recently analysed genetically in Mimulus ${ }^{9}$. The tiny Hylaeus is an unlikely substitute for birds on large flowers like P. tetrapetala, yet we have found that in the absence of birds it can double seed production. Because habitat clearance and introduced mammalian predators in New Zealand have lowered both bird ${ }^{10}$ and mistletoe ${ }^{11}$ densities, this small pollen harvester provides important conservation benefits.

\section{Dave Kelly}

\section{Jenny J. Ladley}

Plant and Microbial Sciences, University of Canterbury,

Christchurch 1, New Zealand

e-mail: D.Kelly@botn.canterbury.ac.nz

\section{Alastair W. Robertson}

Ecology Department, Massey University, Palmerston North, New Zealand

\section{Joan Edwards}

\section{David C. Smith}

Biology Department, Williams College, Williamstown, Massachusetts 01267, USA sites that we studied, but do not open Peraxilla flowers. These flowers are opened only by native animals (whether birds or insects).

New Zealand generally has unspecialized pollination syndromes ${ }^{8}$ and a depauperate fauna (there are no land mammals). This could explain why the only invertebrate known to open birdadapted explosive flowers is found in New Zealand. Elsewhere, changes in pollinator availability in isolated
1. Ladley, J. J. \& Kelly, D. Nature 378, 766 (1995).

2. Ladley, J. J. \& Kelly, D. For. Bird 278, 16-21 (1995).

3. Kuijt, J. The Biology of Parasitic Flowering Plants (Univ. California Press, Los Angeles, 1969).

4. Proctor, M. C. F. \& Yeo, P. F. The Pollination of Flowers 201 (Collins, London, 1973).

5. Aluri, R. J. S. \& Subba Reddi, C. Proc. Indian Nat/ Sci. Acad. B 61, 323-332 (1995)

6. Meeuse, J. D. The Story of Pollination (Ronald, New York, 1961).

7. Donovan, B. J. \& Macfarlane, R. P. in New Zealand Pests and Beneficial Insects (ed. Scott, R. R.) 247-264 (Lincoln Univ. Coll. Agriculture, Canterbury, 1984).

8. Webb, C. J. \& Kelly, D. Trends Ecol. Evol. 8, 442-447 (1993).

9. Bradshaw, H. D. Jr. Wilbert, S. M., Otto, K. G. \& Schemske, D. W. Nature 376, 762-765 (1995) 10. King, C. M. (ed.) The Handbook of New Zealand Mammals (Oxford Univ. Press, Oxford, 1990). 11. Ogle, C. \& Wilson, P. For. Bird 237, 10-13 (1985). 